\title{
VERBAL EXTREMISM AS A FORM OF VERBAL INFLUENCE ON THE RECIPIENT
}

\author{
Inna A. Yaroshchuk ${ }^{1}$, Kristina S. Grigorova², Sergey N. Mamin³, Mihail I. Nikulin², Lyudmila A. \\ Spektor ${ }^{5}$ \\ 1, 3,4 Belgorod State University, 85, Pobedy St., Belgorod, 308015 Russia \\ 2 Pyatigorsk state University, 9, Kalinin Ave, Stavropol region, Pyatigorsk, 357532, Russia \\ 5 The Institute of service sector and entrepreneurship (branch) of DSTU in Shakhty, 147 Shevchenko \\ street, Shakhty, Rostov oblast, 346500, Russia \\ e-mail: yaroshchuk@,bsu.edu.ru
}

\begin{abstract}
This paper determines through the linguistic analysis the possibilities of verbal extremism aimed at manipulation with the actions and behavior of the recipient. The texts presented online in the Internet telecommunication network are investigated. The communicative attitudes to the control over the recipient's behavior, as well as the linguistic features of their implementation in the text are revealed.
\end{abstract}

Keywords: Extremism, verbal extremism, linguistic research, texts of propaganda orientation, propaganda texts, speech manipulation.

\section{INTRODUCTION}

Counteraction to extremism is one of the most important tasks of modern reality. State authorities need to take effective measures and decisions with regard to agreed preventive actions aimed at preventing and suppressing extremism in all forms of its manifestation [1, p. 12].

A rough socio-political situation in modern Russia determines the appeal of researchers of various fields of knowledge to the problem of countering extremism, and studying its specifics and criminallegal characteristics. Among the researchers, whose scientific works are devoted to the study of phenomena of extremism, are Iu.M. Antonian [2], S.V. Borisov [2], G.N. Gorshenkov [3], E.I. Galiashina [1], and others.

Recently, the most widespread is verbal extremism, implemented within the open telecommunication network of the Internet and the media. The term "verbal extremism" has recently been used by many researchers, in particular, it can be found in the works by M.V. Ablin [4], N.S. Gromova [6], E.I. Galiashina [1], A.L. Iuzhaninova [6], N.D. Panteleeva [7] and others. Thus, according to N.S. Gromova, verbal extremism is "a kind of verbal offense that involves the use of a set of linguistic means by a subject in the process of oral or written speech for the implementation of extremist activity" [5, p. 146]. Consequently, counteraction to aggressive information is a priority for state authorities and society $\mathrm{n}$ general through filtering and blocking of relevant Internet websites and other resources of the global network $[8,9]$.

The most urgent expert problems are associated with the study of extremist texts in such categories of criminal cases as public calls for the implementation of extremist activity (Article 280 of the Criminal Code of the Russian Federation), incitement of hatred and enmity, humiliation of human dignity (Article 282 of the Criminal Code), in civil cases associated with the application of the Federal Law "On Counteracting Extremist Activity" \# 114-FZ of July 25, 2002, in arbitration cases associated with the contestation by legal entities of various regulations and warnings issued by federal services.

\section{METHODOLOGY}

The paper uses a method of conceptual analysis, lexico-semantic and semantic-syntactic analysis, analysis of the structural organization of the text, linguistic analysis, methods of component analysis, and analysis of presuppositions. 


\section{DISCUSSION AND RESULT}

In linguistic terms, verbal extremism is used to influence the addressee to manipulate his/her actions. Thus, the Internet environment is the most popular sphere of realization and functioning of extremist texts. Depending on the target, they include propagandistic and agitation texts. These targets are usually implemented simultaneously. The texts contain information that can influence the formation of certain ideological views in the addressee and, at the same time, call for certain actions. That is, the propaganda focus of information is the basis for the implementation of agitation information. First of all, the works by the leaders of the fascist party in Italy, Germany, text (or graphic, audio, video) publications and statements of nationalist writers, followers of the ideology of fascism, grounding or justifying national or racial superiority or justifying the practice of committing military or other crimes aimed at the total or partial destruction of any ethnic, social, racial, national or religious group. The Internet is a space where these texts are gaining popularity. An example of such a text is the article "Adolf Hitler. Life for Germany and Europe" by Thies Christophersen, a German writer and publicist of a nationalistic ideology, an adherent of fascist ideology; this article is published online in the Internet. Its text contains:

- statements containing a positive assessment, support and justification of fascist ideology:

"Terrible was the war, a war that Adolf Hitler certainly had not wanted. But he also could not prevent it ... <... > This book is not only a vindication of Adolf Hitler but also of all those who faithfully followed the Führer ... <...> Much of it will remain unforgettable to us. There was no state moroseness, and no unemployment. Community among people and enthusiasm flourished ... <...> »;

- statements about the advantage, superiority of one group of persons in front of other people, united on the basis of race, nationality, language, and origin. The superiority and exclusiveness of the German people in comparison with other peoples and countries of the world is expressed at the level of the nominative representation of individual states and their representatives. On the one hand "German Empire", "Great Germany" "Great German Empire", "Great German Wehrmacht" "exhausted German people", "the brilliant creation by Adolf Hitler", "great people". "Their talent for organization would have created order and peace in Europe within a short time. They would have created the "United States of Europe" without bloodshed and provided their skills in the sciences, arts and technology to the whole world, as they did before. Their intellectual life, especially the exceptional German music, would have enriched the existence on this earth." On the other hand - "a bunch of courageous", "red terrorists", "international warmongers", "American Wall Street mafia", "rascals", "a group of Red Front militants", "red rabble", "a cabal of unscrupulous traitors" (about the winners of the Second World War);

- motivational statements, calling for hostile actions of one group of persons in relation to another, united on the basis of race, nationality, language, and origin:

"German men and women, soldiers of the German Military! The Führer has chosen me as his successor. Conscious of the responsibility, I take over the leadership of the German people in this fateful hour. My first duty is to save the German people from annihilation by the advancing Bolshevik enemy. Only for this goal the military battle continues... $<\ldots>$ For all of this, I need your help!"

This article is an example of the implementation of an explicit extremist information in the Internet space.

However, most often extremist information presented in the Internet is implicit, veiled as a personal author's opinion, messages, remarks, etc., and, accordingly, at first glance, makes no calls. For example:

"But why?! Why!!!! Why you need to call and mine supermarkets, markets and metro !!!! If you do not like this power so much, which, in your opinion, does something wrong, why not lay mines in the administrative buildings? If only during the inauguration of a governor someone called, it would be fun to watch the "best people of the city" running, dropping their Breguet in flurry and scattering pearl beads on the marble steps."

The nature of the above communicative construction, which the motivation addressee uses, is implicit: a complex sentence with a prerequisite part of the condition ("If you do not like this power so much, 
which, in your opinion, does something wrong") + the main part with an implicit communicative construction: "why" + "not" + infinitive ("why not lay mines in the administrative buildings?"). Further, in order to induce the addressee to take actions and call to inform about mining during the inauguration of the governor, the addressee uses the communicative construction of the implicit sentence by using the subjunctive mood in the subordinate part of the complex syntactic structure as the conditions for "having fun" and cheerily watching the escape of "the best people of the city". It is an author's implicit call for the implementation of a certain action (in this case, a "call" during the inauguration of the governor) by the addressee, whose implementation depends on him and on his choice and with the possible involvement of others (as indicated by the use of the pronoun of the 2 person plural " $\mathrm{ou}^{\circ}$ ").

The object of action the addresser calls the addressee for, is a group of persons united by the sociopolitical sphere of activity. According to the author's nomination - this is "power" (governor, "the best people of the city", representatives of the administration).

Thus, the above application text is built on the principle of verbal manipulation. The author seeks to realize the implicit introduction of a personal idea and opinion into the consciousness of the addressee in order to urge him/her to carry out hostile actions against members of the socio-political sphere.

As E.V. Cherniavskaia aptly notes, the distinguishing feature of verbal extremism is the nonrecognition by the addressee of a communicative attitude to the control of his/her behavior or change of his/her opinion [10], that is, the addressee is able to carry out a certain action in the interests of the addresser without realizing the consequences.

The addressers of texts with extremist ideas use a variety of ways of verbal manipulation, which finds its realization within the framework of religious discourse, religious and ideological opposition, projected primarily as a Muslim world - the Orthodox world. It is, first of all, propaganda of extremist ideas for the purpose of involving followers, where special methods of neurolinguistic programming and verbal zombification are used. The addressee can also be involved through the distribution of special literature capable of changing ideological, religious views [6]. The sharpened emotional background of the information reported causes the addressee's productive perception of the ideas presented in the text. As a rule, there are no rational, objective, definitive arguments; the main means of information transmission are emotionally, stylistically marked vocabulary, religious vocabulary, which helps create a vivid image of the enemy:

"I appeal to you, brother! Look around you, open your eyes wider, think with your head, or you lost your sight and can't see that all the countries of the world are the inveterate enemies of Allah, hypocrites and cowards, obedient slaves, descendants of pigs and monkeys, evil spirits, spineless servants ... They gathered for war with an Islamic state ... So hurry to the camp! You must realize the full burden and sinfulness of your position and sincerely ask forgiveness from Allah, saying that you do not plan to continue such a life ... <... Muslims are oppressed all over the world, so the brothers tossed a challenge ... <...> These lions rose up to free the Muslims from the rest of the dirty world and build the Caliphate ...

The means of dialogization used by the author exert a strong influence on the addressee. Appeals, rhetorical calls, imperative constructions, along with an orientation toward individualization of the reported statement provoke a person to express his/her thoughts and feelings, which later can be used by extremists for manipulation. The contextual synonymic series used by the author (inveterate enemies of Allah, hypocrites and cowards, obedient slaves, descendants of pigs and monkeys, evil spirits, spineless servants), which actualize the discord between the Muslim world and the religious world, also appear to be effective. This, in turn, foments enmity and hatred in the world community. Simultaneously, against the background of the negative image of one group, a positive image of the other ("brothers", "lions") is formed. This ensures a productive perception of the fundamental characteristics of opposing groups by the addressee, according to the author's opinion.

To successfully manipulate the recipient, the addresser uses the most up-to-date information. Extremist texts reflect key features of a social, political, ideological nature, as a rule, of a conflictual orientation. 
Thus, the authors of extremist texts achieve the recognition of information, its relevance, ensuring its active dissemination in the Internet.

\section{SUMMARY}

Thus, verbal extremism is a special form of verbal (most often implicit) influence on the consciousness of the addressee and the form of manipulation of his/her behavior. As a result, the recipient is able to commit unlawful acts that threaten social and political security. During this impact, the addressees of extremist texts use various techniques for the purpose of propaganda and agitation, aimed at effective information perception, taking into account the subjective and social characteristics of the addresser in order to actualize enmity, discord among groups united on the basis of social affiliation, race, nationality, religion, or language. A successful result of the impact on the addressee is provided by the presence of a certain set of knowledge regarding the recipient's personality in the addresser. Consequently, it seems possible to argue about the personality-oriented nature of verbal extremism.

\section{REFERENCES}

Galyashina, E.I. 2006. Linguistics vs extremism: a guide for judges, investigators, experts / Under the editorship of Professor M.V. Gorbanevskaya. Moscow: Legal World. 96 p. (in Russian)

Borisov, S.V. 2012. Qualification of the riots, hooliganism and extremist crimes: theory and practice / S.V. Borisov, O.P. Dmitrenko, V.A. Osipov, E.A. Ruszkiewicz; resp. N. The Town Of Kadnikov. Moscow: Jurisprudence. 120 p. (in Russian)

Gorshenkov, G.N. 2011. Countering extremism : teaching manual. N. Novgorod. 733 p. (in Russian)

Ablin, M.V. 2012. Extremism and extremist materials in jurilinguistic. Bulletin of the Chelyabinsk state University. \# 36 (290). pp. 5-8. (in Russian)

Gromov, N.C. 2016. Verbal extremism as a form of speech manipulation by the addressee. Collection of materials of the Internet conference "Language and law: actual problems of interaction". pp. 145-151. (in Russian)

Yuzhaninova, A.L. 2008. Questions of a technique of judicial psychological examination of verbal extremism. Forensic examination. \# 3. pp. 43-50. (in Russian)

Panteleev, B.N. 2011. Objective criticism or verbal extremism. the Ezh-Lawyer. \# 29. pp. 1-3. (in Russian)

Kobzeva, S.V. 2009. Countering the aggressive disclosure of information. Moscow. Librokom. 64 p. (in Russian)

Chepovskii, A.M. 2015. Information model in tasks of processing of texts in natural languages. M. 276 p.

Chernyavskaya, V.E. The Discourse of power and the power of discourse: problems of speech influence: study guide / 2nd ed., erased. M.: FLINTA, Nauka. 136 p. (in Russian)

Dijk, T. A.van. 1977. Text and context. Explorations in the semantics and pragmatics of discourse. London and New York: Longman. pp.261.

Jaynes, J. 1976. The Origin of Consciousness in the Breakdown of the Bicameral Mind. Houghton Mifflin Company. pp. 476.

Austin, John 1986. Word as action: New in foreign linguistics. 17. The theory of speech acts. M.: Progress. pp. 22-129.

Lakoff, J. 1988. Cognitive semantics Meaning and mental representations. Bloomington. pp.78-106. 